\title{
Some Reform Ideas for the Software Project Management Course
}

\author{
Liping $\mathrm{Li}^{1,}$, Tang Shan ${ }^{1, b}$ \\ ${ }^{1}$ Computer and Information Institute, Shanghai Second Polytechnic University, Shanghai, 201209, \\ China \\ aliliping@sspu.edu.cn, ${ }^{\text {b }}$ tangshan@sspu.edu.cn
}

Keywords: Software Project Management, Course Reform, Project-driven, Case Study.

Abstract. Aim at the general problem of software project management curriculum, this paper proposes some reform ideas for the course teaching, including improve teaching mode, teaching methods. We use project-driven, scenario teaching, case studies teaching and large software project management simulating to enhance students' learning enthusiasm, transfer their passive learning to active learning. Result showed these methods have gained some good effect, improved the teaching quality.

\section{Introduction}

Software project management is one of the core curriculums for the students of software engineering major in ordinary colleges and universities. The main purpose of software project management is trying to solve the software crisis using scientific management method. It aims to make the software project complete successfully according to preplan cost, schedule, scope, quality and so on. Software project management curriculum has a very important significance to cultivate software engineers. Through this course study, hope students understand the basic theories, methods and techniques of software management. However, for most undergraduate who without any experiences in software project development and management, they felt that the content is baldness, useless and difficult to understand. "Project management have nothing to do with me?", "It likes the politics course", "It's not too late to learn it if I'm a project manager ". Under the control of such views, most students do not learn the course hard, just only to pass the exam. It makes the teaching of this course is difficult and cannot attain the teaching purpose and guarantee teaching quality. And survey shows the current software project management curriculum is not up to the mark and need some revision [2].

This article proposes some reform ideas for software project management course. Take advantage of the advanced teaching methods and experience in the project management at home and abroad, ready to reform on the teaching mode, teaching methods, teaching means and teaching resources etc. The purpose is to create a good learning atmosphere, change passive learning into active learning, enhance students' interest in learning, let them better understand and use the knowledge to solve actual problems. We mainly use project-driven and case-driven teaching mode, which would benefit to the talent training for the software industry.

\section{Core idea of software project management}

Software project management is the application of knowledge, skills, tools and techniques to project activities to meet project requirements and is delivered on time and on budget [3]. The teaching objective is training the students' abilities to manage and control project processes, and developing their team skills.

Software project management is a course which has certain degrees of difficulty and span. Students should acquaint nine knowledge areas of "Guide to the Project Management Body of Knowledge" (PMBOK® Guide). It has five standardization processes: Initiating Processes, Planning Processes, Executing Processes, Monitoring and Controlling Processes, and Closing Processes [1]. The Initiating Processes defines and authorizes the project or a project phase. The Planning Processes 
defines and refines objectives, and plans the course of action required to attain the objectives and scope that the project was undertaken to address; The Executing Processes integrates people and other resources to carry out the project management plan for the project; The Monitoring and Controlling Processes regularly measures and monitors progress to identify variances from the project management plan so that corrective action can be taken when necessary to meet project objectives. The Closing Processes formalizes acceptance of the product, service or result and brings the project or a project phase to an orderly end.

However, most of the current textbook of the software project management is too theoretical. The abstract and theoretical knowledge of the content make students cannot understand the course deeply, so students' learning motivation is not very strong. In order to grasp the principles of software project management, a lot of practical experience is required associate with theoretical knowledge in the textbook [4]. But most students have not chance to do the practical projects, so there is no concept of project management. The traditional teaching approach is inclined to make students lose interest for the curriculum which focus on a lot of practice experience. Therefore, how to keep software project management courses vivid, let students shift from passive learning to active learning, from no interest to rapture to the class, increase the practical teaching of the course, theory contact with practice is the focus of the course reformation.

\section{The Reform of Software Project Management Course}

Good cases and experience is very important for software project management. According to statistics, only about $29 \%$ of the software project can be accomplished successfully. Based on the experience of project management consulting and software providers, there are a lot of IT companies have been repeating some mistakes all the time. In general, the errors in the IT department in project management are mostly caused by improper planning or communication. These errors seriously reduce the project's success chances. In order to learn best practice, we proposed project-driven and case-driven method, "hierarchical" teaching content of course based on many successful software project cases. Students not only should have enough theory knowledge, but also should hands on experience on related Project Management tools like Microsoft Project, IBM Rational Portfolio Manager etc.

There are some reformations in teaching mode and teaching means to explore:

1) Theory Teaching

First of all, in order to improve student's active participation in class, let students know they can ask questions anytime in classes if they have questions, teachers should answer the questions from the students and often ask a few more words like "Is there a problem?" after one knowledge point is finished.

Second, play some actual scene video about software project management to let students understand the importance of software project management. Vivid classroom atmosphere, improve the students' interest in learning. For example, we simulate the scene of project tender when we talk about the project Initiating Processes, depart students into two teams, one is customer, one is Software Company.

Third, students are required to reading relevant texts and papers; they should write a survey report about software management present situation and the significance of project management by collecting the news from website, newspaper or magazines.

Fourth, case-driven teaching mode is the best for students to understand the theory in the book. We select several appropriate cases study to help students understand the actual processes of project management.

2) Practice Teaching

In the actual practice process, it's important to show the students abilities of cooperating, planning, learning, communicating, expressing and leading [3]. Actually, these abilities could be improved only by practice. In the curriculum, we use project-driven mode. Students are required to work in 
teams of 5-6 persons. Each team should manage a project with given tasks. Every person could be the manager of the team in different tasks.

The project proposals must be submitted at the Initiating Process. The project supervisor (teacher) reviews the proposals and approves or rejects the respective proposals [5]. Project manager tracks the project plan and manage the whole process. In order to make every student experience the management process better, they are required to act as different manager. The whole management process simulates Software Company with hierarchical management. Project manager of each team is responsible for their project's completion and management phases, and each member of the group responsible for their own role to the project manager. This can enable students understand the software company's management style, experience a sense of teamwork, increase management awareness.

At the same time, each team should complete some important work of software project management, include project schedule, project cost budget, team organization, and risk planning, communication planning etc. They must submit the documentation, like project chart, WBS and final report. For the submitted documentation, the project charter is to identify the exist of project, mandate of the project manager etc. Project development plan, including time schedule, cost plan, quality assurance and configuration management plans; other documents are submitted in accordance with the various stages of software management. All the documents must submit in accordance with the standard document templates.

Assessment methods are an important part of this project-driven teaching model [5]. Assessment takes place in the whole practice process. At each phase, choose one group to describe the project management and control process in class, other teams can comment and ask questions. The teacher reviewed and summarized. Students should revise their project plan according to the comments. At the final acceptance phase, each team should clear up their project and prepare for an oral defense.

For the course score, given the right to project manager, team members are assessed by the project manager. The manager should submit his/her grades to the teacher and the teacher reviewed the grades according to submitted documentations and project oral defense. Each team has a report based on project practice and shares their experiences. At the project oral defense, every member needs to explain his responsible work, teacher would ask some questions, reviewed and summarized. Finally, the course score is composed by four parts, submitted documentation (30\%) + project oral defense $(40 \%)+$ team collaboration $(20 \%)+$ discipline in class $(10 \%)$. Generally, project manager's score is his team scores fluctuations $5 \%$.

In order to make the project complete successfully, get high grades, students have to complete the assigned tasks, because the report is ongoing according to roles. Though the project practice, the students could gain better understanding of the concepts and principles in the books.

Different from the traditional teaching mode, our teaching mode has some advantages.

1) Transfer passive learning to active learning.

In our traditional teaching mode, the students have no practice experiences and feel this curriculum is too boring, which results in passive learning. In our new teaching mode, we not only teach them the software management concepts by cases study, but also let them know why they should learn it from actual scene video and relevant texts and papers.

2) Convert the cramming method to acquiring knowledge through practice [4].

The traditional teaching process in my school is that teacher speaks while the students listening. There is no practicing at all, which decreases the students' interests since they lack experiences. In the new teaching activities, the students could gain better understanding of the concepts and principles in the books though project practice. When they encounter some problems, the teacher could offer some advice and the students should solve problems by themselves.

3) Project-driven method emphasizes not only the result of the project, but also on project management process. Our project teams simulate software company's project teams. Scores of students simulate the bonus of company employees. 


\section{Summary}

This paper proposes some practical advices for software project management curriculum. In our teaching mode, we teach students the concepts and theory by appropriate cases study. During the actual practice process, we use project-driven method to let students manage and control some projects. They are required to grasp some related project management tools like Microsoft Project, IBM Rational Portfolio Manager to help managing the project. Our reform emphasizes not only the result of the project, more focuses on the process of project development and management. Results showed this attempt can improve the teaching effect of this course. It can foster students learning interest and make them gain better understanding of the concepts and principles of software project management though project practice.

\section{Acknowledgements}

This work was financially supported by Innovation Program of Shanghai Municipal Education Commission (11YZ251).

\section{References}

[1] PMI, A Guide to the Project Management Body of Knowledge (PMBOK Guide) Third Edition.2004.

[2] Abdul Rauf, Ibrahim Albidewi. Improvement in Course Curriculum for Software Project Management. The 3rd International Congress on Engineering Education (ICEED). 2011, pp125-127.

[3] Longjun Huang, Liping Dai, Bin Guo etc. Project-Driven Teaching Model for Software Project. International Conference on Computer Science and Software Engineering. 2008, pp 503-506.

[4] Gabriele Bavota1, Andrea De Lucia etc. Teaching Software Engineering and Software Project Management: An Integrated and Practical Approach. ICSE 2012, Software Engineering Education. Zurich, Switzerland. 2012. pp 1155-1164.

[5] Kan Yimei. The Practise and Examine of Software Project Management under simulative Project [J]. Computer Education.2007,(3):26-28. 